\title{
Creative leadership: presumptions and methods of realization
}

\author{
Maria Avakyan \\ Russian-Armenian University \\ 123 Hovsep Emin str, 0051, Yerevan \\ Republic of Armenia \\ e-mail: marvolskaya@gmail.com
}

\begin{abstract}
The concept of "leadership" is thought to be a special, profitable situation inside a specific social group presupposing the influence on other individuals with the aim of subsequent attaining of goals, i.e. perfection, leadership, career advancement, etc. Leaders have always existed, both in the animal world and in different human formations. The questions of origin of the concept "leadership" interested Aristotle and Plato, and later other scientists devoted considerable attention to this issue.

This contribution discusses presumptions and methods of realization of what we call the "creative leadership". It analyses the dilemma of creative leadership and discusses how this concept differs from the political leadership. Moreover, it uses several examples and case studies from Armenia to prove its point. All in all, the contribution offers an interesting methodological insight into the concept of leadership from the point of view of philosophy, linguistics, semantics, and history.
\end{abstract}

\section{Introduction}

According to Plato, a perfect state itself brings up its governor-philosophers basing on their gifts and talents but exercising much effort for their education and directing them from the "night" day to the "authentic day of the being" (Takala 1998).The main point of confrontation among the scientists which has not yet found its solution is the issue whether leadership skills are inborn or are required as a result of behavioral activity.

For example, Francis Galton was sure that leaders are born as such. Interestingly, Galton was a cousin of Charles Darwin, by their common grandfather, Erasmus Darwin. His father was Samuel Tertius Galton, the son of Samuel (John) Galton. The Galton family was well known and very successful in the sphere of weapons manufacturing and banking, while the Darwins were known in the fields of medicine and science (Browne 1981). Both families could boast the fact that their representatives were members of the Royal Society of London, which later became the British equivalent of Academy of Sciences, and they were keen on inventing in their spare time. Both Erasmus Darwin and Samuel Galton were among the founders of the famous Lunar Society of Birmingham, among whose members were Matthew Boulton, James Watt, Josiah Wedgwood, Joseph Priestley and other outstanding scientists and entrepreneurs. Also, both families showed literary talents: Erasmus Darwin, known for creating long technical treatises (textbooks) in poetic form, and Aunt Mari-Anna Galton, known for her works on aesthetics, religion and her famous autobiography detailing the unique environment of her childhood, consisting of members of the Lunar Society.

In the same time, Cecil Rhodes propagated the idea of educating a leader out of any student given due education. Cecil John Rhodes was a South African politician and entrepreneur, a figure of British imperialism, the organizer of British colonial expansion in South Africa, the "architect of apartheid". Between 1890 and 1896 , he headed the Cape colony. Northern Rhodesia (now Zambia) and Southern Rhodesia (now Zimbabwe) was named in honor of Rhodes.

At present social psychology dedicates considerable attention to the issue of leadership: depending on the tools which the leader uses, several leadership styles were revealed: autocratic, democratic, liberal, narcissistic, toxic, result-oriented or relations-oriented. As Strielkowski and Chigisheva (2018) state, any form of leadership (social, economic, and academic alike) is becoming a key element for the future sustainable development of business and education in the quickly globalizing world. Leadership is becoming a purpose of higher education and postdoctoral research work (Strielkowski 2018). It seems to be quite important to assess the state of public leadership theory and research and to draw a path forward for helping to understand the continued appeal of Great Person leadership and the promise of collective leadership, as Crosby and Bryson (2018) point out. 
In this paper, I analyze the phenomenon of leadership with a special focus on Armenia and Armenian leaders. Moreover, I contemplate on the presumptions and methods of realization of what can be called the "creative leadership".

\section{Leadership and governance}

One of the key moments of the scientific dilemma is the differentiation between the terms "leadership" and "governance" (Jankelová et al. 2017). A leader is responsible for interpersonal relations whereas a supervisor is responsible for formal relations (Moskalenko and Yevsieieva 2015). Leadership, as opposed to supervision, is always a haphazard process. Even though, the range of activity of the supervisor is wider due to a wider access to information and levers. One can clearly see that leadership is in fact a very complex concept and a set of ideas, rules and norm that can be viewed and therefore has to be studied in the multidimensional perspective using various tools and methods (Selyanskaya et al. 2018).

The topic of our research is, first of all, creative leadership. This paper attempts to describe it, classify it and make some example of it. The topic seems to be very important since alongside with political leaders it is the creative leaders who have frequently changed the image of any given country (and, in fact, the world). In the designated problem a construct which is central for further social and psychological research of creativity can be revealed. This is the study of creative leadership as specific (personalizing) influences of the subject on other subjects. This phenomenon includes actualization of individuality (individualization) of the members of the group, reflection and acceptance (integration) of the individuality of the leader which secure effective combined creative activity (Mueller et al. 2011).

According to some researchers, today social request of training "of leaders transforming reality", "innovative leaders" is formed: such leaders are capable of coming up with new ideas and standards, can inspire the workers to realize the project, give birth to their individual and creative growth. Such leaders appear in organizations spontaneously as a response of gifted people to the challenges of the time. Creative leadership is a central construct in the research of overcoming conflicts of a creative person with the social surrounding, breaking of the value conflict of the society and realization of mass creativity, supporting the work of creative people in complicated heterogeneous groups (teams). For instance, Kark and Van-Dijk (2007) stated that Higgins put forward Regulatory Focus Theory (RFT) extending the basic hedonic principle that people are motivated to approach pleasure and avoid pain, and in the purpose of a new explanation of people's motivation, revealed that how humans approach the positive target and avoid the negative. The theory distinguished two different orientations: prevention focus and promotion focus.

\section{Leadership in Armenia: selected examples}

However, from our viewpoint, the formation and rather the emergence of the leader is a complex, multi-sided process, especially in the modern society when the society is ready to follow even the individual leader who can reflect their interests and hopes as it happened in Armenia during the recent "velvet", or "bloodless", revolution in spring 2018. The results of the phenomenon are yet to be studied. But already today it is clear that the phenomenon of the leadership of Mr. Pashinyan has historical, social and existential-humanistic and other roots.

In the leader of the all-nation Armenian movement, Nikol Pashinyan, it is not the attributes of the manipulation of the crowd that matter: here we will have to adhere to the opinion that people are a faceless mass, but the spirited addressing of the person to a person, patriot and citizen. The message that Mr. Pashinyan sends to the nation, to reveal its national self-awareness and citizenship is as follows: It is you who has won, the citizen of the country. You, just you can change the country. But you should believe in yourself, in your own power. That the leader turns to each person is, from the positions of existential and humanistic approach, a declaration of the self-value of the individual. Nikol Pashinyan, a unique person in his charisma, talent, energy and love towards the person, kindness, desire for freedom and justice, stimulates and boosts the emergence and revealing of the best in the person: patriotism, love towards people, benevolence, enthusiasm, humanity, emergence of the inner Leader in everyone. Mr. Pashinyan seems to say out loud: "I am a value. I can realize myself and self-realize in my homeland, in my beloved Motherland". This explains the uniqueness and exceptionality of the protesting movement and velvet revolution in Armenia" (Berberyan 2018). Here, I would like to add that the image of the new leader would not be complete without taking into consideration the "creative" past of Mr. Pashinyan as a professional journalist which means that the formation of his political, social and moral traditions is based on the journalistic heritage of the Armenian culture. "Eastern value systems suggest the possibility of the leadership through the achievement of the moral authority. That 
is, the moral authority allows you to not only avoid conflicts, especially at the household level, but also to win the sympathy and respect in interstate and intercultural relationships" (Suvorov et al. 2017).

Back in the past Machiavelli (1961) discussed the role of the leader in the society: in his essay "The Sovereign" he guides the reader into the new world of politics where the issue of leadership is raised anew. The new state phenomenon should, according to him, be headed by a new ruler. Machiavelli turns to the ancient political samples and suggests as the best form of the governance the republic of Roman type that is why its new ruler is not the emperor, the tsar or the sultan but the princeps, i.e. "ruler" or "prince". Thus, the new ruler is both a person of fortune and a person who has his freedom of will (Lucchese 2017).

Here, naturally, there arise specific parallels. Both in Armenian history, and in the history of the philosophical idea and culture there have been quite many "creative" leaders starting from the ancient times: the creator of the Armenian alphabet Mesrop Mashtots, philosopher David Ankhakht, historian Movses Khorenatsi, representative of the early Armenian Renaissance, poet and religious leader Grigor Narekatsi; the founder of the Armenian Liberal movement Hovsep Emin, Catholicos of All Armenians who protected people in conditions of absence of the Armenian state and the leader of the Armenian Liberating movement Mkrtitch Khrimyan (Hayrik), a scientist, founder of the Armenian Catholic Order of Mkhitaryans Mkhitar Sebastatsi, founder of the early Armenian Liberating movemennt Israel Ori, a national hero of Armenia, military leader and philosopher, author of books which largely defined the process of formation of the Armenian national ideology Garegin Nzhdeh (Ter-Arutyunyan), a lawyer, writer, member of the Osmani parliament, and deputy voicing protection of Armenians in the Ottoman Empire Grigor Zohrab, and many others who defined and changed the fate of people and who had an invaluable contribution in the history of Armenia. That is why, when the time comes, political leaders are born whose basis is the concept of "creative" superiority with high moral norms. According to an ancient Armenian philosopher David Anhaght, practical philosophy basing on the results of the theoretical philosophy, should lead people's spirits to moral virtues to point the ways how to avoid the evil, to seek for spiritual rise and self-perfection constitute the main mission of philosophy in general (Anhaght 1960).

According to Zubanova (2009), the idea of leadership as a most accepted and anticipated image of the leader has resulted in a series of changes and transformations: leader-hero, leader-ruler, leader-prophet and so forth (Zubanova 2009).

Sooner or later a theoretical basis is formed around the image of the leader and exercises the function of his ideological grounds, revealing the unique set of interpretation of leadership qualities: a concept of heroism or leadership, messiahship or a theory of ideal governance, effective leadership and management, etc.

One cannot help but agree with the idea that $21^{\text {st }}$ century dictates new models of leadership. The basis of the modern theories of leadership is comprehension of the world as dynamic, constantly changing, risky and complicated (Lewis et al. 2017). Thence, transition to a new philosophical paradigm, to a new interpretation of perception and understanding of the world creates completely new concepts of leadership.

\section{Concluding remarks}

In conclusion, I have to summarize my thoughts and concept on the topic by stating as viewed by scholars and scientists, "leadership" is considered to be a special, profitable position within a certain social group, implying influence on other members of this group to subsequently achieve certain tasks. One of the key moments of the scientific dilemma of this topic is the problem of separation of the concepts of "leadership" and "management." A leader is responsible for interpersonal relations, while a manager deals with formal relations. A leader is a representative of the group, whereas a manager is clearly abstracted from it. Leadership, unlike management, is always a spontaneous process.

According to many researchers and thinkers, today a social request is being formed for the preparation of "leaders transforming reality", "innovative leaders"; that is, leaders of this type are able to offer new ideas or standards, inspire people to implement the project, generate their personal and creative growth.

All in all, in our opinion, the "birth" of a leader is a very complex, multifaceted process, especially in the modern society that is subjected to the plethora of ideas, concepts, and the free flow of information from the Internet and various social networks. There should be a momentum and the consensus achieved in the exact spot of time when the society is ready to follow even a single leader capable of reflecting their interests and aspirations, as it happened in Armenia during the so-called "Velvet" revolution in the spring of 2018. However, in the course of time and with the passing of regimes, political ideas and concepts, alongside the image of the leader, there is a theoretical basis that fulfills the function of its ideological justification, revealing a peculiar set of interpretation of the nature of leadership. 


\section{References}

Allio RJ (2015) Good strategy makes good leaders. Strategic Leadership 43(5):3-9. doi: 10.1108/SL-07-2015-0059

Anhaght D, Definitions of Philosophy. $1^{\text {st }}$ edn. (Translation from the ancient Armenian. The foreword and comments by S.S. Arevshatyan, Scholars Press, Yerevan, 1960), 200 p.

Berberyan A (2018) The phenomenon of the Armenian national movement. http://megapolis.am/index.php/news/9/2041-fenomen-armanskogo-obsenarodnogo-dvijenia.html Accessed 25th of May 2018

Browne J, Darwin's Origin of Species: a biography, $1^{\text {st }}$ edn. (Grove Press, New York, 1981). 179 p.

Crosby BC, Bryson JM (2018) Why leadership of public leadership research matters: and what to do about it. Public Management Review 20(9):1265-1286. doi: 10.1080/14719037.2017.1348731

Jankelová N, Jankurová A, Masár D (2017) Effective management and self-government: current trends. Czech Journal of Social Sciences, Business and Economics 6(2):21-31. doi: 10.24984/cjssbe.2017.6.2.3

Kark R, Van Dijk D, Vashdi DR (2018) Motivated or Demotivated to Be Creative: The Role of Self-Regulatory Focus in Transformational and Transactional Leadership Processes. Applied Psychology 67(1):186-224. doi:10.1111/apps. 1212

Lewis E, Boston D, Peterson S (2017) A Global Perspective of Transformational Leadership and Organizational Development. Journal of Research Initiatives 2(3):5.

Lucchese FD (2017) Machiavelli and constituent power: The revolutionary foundation of modern political thought. European Journal of Political Theory 16(1):3-23. doi: 10.1177/1474885114544911

Machiavelli N, The Prince; Transl. from the Italian, $1^{\text {st }}$ edn. (Penguin, New York, 1961), 144 p.

Moskalenko V, Yevsieieva I (2015) Effective leadership conflict management in food technology enterprises. International Economics Letters 4(2):91-102. doi: 10.24984/iel.2015.4.2.4

Mueller JS, Goncalo JA, Kamdar D (2011) Recognizing creative leadership: Can creative idea expression negatively relate to perceptions of leadership potential? Journal of Experimental Social Psychology 47(2): 494-498. doi: 10.1016/j.jesp.2010.11.010

Selyanskaya G, Finogenova Y, Strielkowski W (2018) Factor Analysis of Economic Leadership Peculiarities of Countries and Regions Around the World. In: Strielkowski W., Chigisheva O. (eds) Leadership for the Future Sustainable Development of Business and Education. Springer Proceedings in Business and Economics. Springer, Cham, pp. 213-222. doi: 10.1007/978-3-319-74216-8_22

Strielkowski W, Chigisheva O (2018) Social, Economic, and Academic Leadership for Sustainable Development of Business and Education in the Future: An Introduction. In: Strielkowski W, Chigisheva O (eds.) Leadership for the Future Sustainable Development of Business and Education. Springer Proceedings in Business and Economics. Springer, Cham, pp. 3-8. doi: 10.1007/978-3-319-74216-8_1

Strielkowski W (2018) A postdoc's purpose. Science 360(6384):27-27. doi: 10.1126/science.aat6008

Suvorov V, Fakhrudinova E, Dubrovskaya S (2017) Leadership and Moral Authority in the "Vostochnichestvo" of E.E. Ukhtomsky and the Philosophical Systems of Buddhism and Confucianism. In: Strielkowski W., Chigisheva O. (eds.) Leadership for the Future Sustainable Development of Business and Education. Springer Proceedings in Business and Economics. Springer, Cham, pp. 59-67 doi: 10.1007/978-3-319-74216-8_22

Takala T (1998) Plato on leadership. Journal of Business Ethics 17(7):785-798

Zubanova L (2009) Intellectual leadership: from the prophet to the expert. Bulletin of the Chelyabinsk State University 29(167):51-53. 